\title{
Influence of temperature on continuous high gravity brewing with yeasts immobilized on spent grains
}

\author{
Giuliano Dragone · Solange I. Mussatto • \\ João B. Almeida e Silva
}

Received: 29 April 2008/Revised: 12 July 2008/Accepted: 17 July 2008/Published online: 5 August 2008

(C) Springer-Verlag 2008

\begin{abstract}
Flavor compounds' formation and fermentative parameters of continuous high gravity brewing with yeasts immobilized on spent grains were evaluated at three different temperatures $\left(7,10\right.$ and $\left.15^{\circ} \mathrm{C}\right)$. The assays were performed in a bubble column reactor at constant dilution rate $\left(0.05 \mathrm{~h}^{-1}\right)$ and total gas flow rate $\left(240 \mathrm{ml} / \mathrm{min}\right.$ of $\mathrm{CO}_{2}$ and $10 \mathrm{ml} / \mathrm{min}$ of air), with high-gravity all-malt wort ( $15^{\circ}$ Plato). The results revealed that as the fermentation temperature was increased from 7 to $15^{\circ} \mathrm{C}$, the apparent and real degrees of fermentation, rate of extract consumption, ethanol volumetric productivity and consumption of free amino nitrogen (FAN) increased. In addition, beer produced at $15^{\circ} \mathrm{C}$ presented a higher alcohols to esters ratio (2.2-2.4:1) similar to the optimum values described in the literature. It was thus concluded that primary high-gravity $\left(15^{\circ}\right.$ Plato $)$ all-malt wort fermentation by continuous process with yeasts immobilized on spent grains, can be carried out with a good performance at $15^{\circ} \mathrm{C}$.
\end{abstract}

Keywords Beer - Continuous fermentation ·

High gravity brewing - Immobilized yeasts - Spent grains · Temperature

G. Dragone $\cdot$ S. I. Mussatto · J. B. Almeida e Silva Department of Biotechnology, Engineering College of Lorena, University of São Paulo, Lorena, SP, Brazil

G. Dragone $(\square)$

Departamento de Engenharia Biológica, Universidade do Minho, Campus de Gualtar, 4710-057 Braga, Portugal

e-mail: gdragone@deb.uminho.pt

\section{Introduction}

Actually, industries must be more and more efficient to survive in a competitive and global world. As a consequence, a great interest in finding innovative processes able to be performed with lower cost without affecting the quality of the product has been generated. During the past 35 years, brewing research has been focused on less expensive procedures for the production of high-quality beers. As a result, high gravity brewing, a process which employs worts of higher than normal extract concentration (12 ${ }^{\circ}$ Plato), has been proposed [1-3]. One of the advantages of this process is the reduction in the volume of water used for wort production, which enables increasing beer output without necessity of expanding the equipments capacity for wort preparation, fermentation and storage of the product [4]. In economic terms, the increase of the wort concentration from 12 to $15^{\circ}$ Plato reduces energy consumption in $14 \%$ and improves the process productivity in up to $35 \%$ $[5,6]$.

Continuous fermentation system is another innovative process that provides several advantages compared with the traditional discontinuous fermentation procedure, including a reduction in the equipment and plant sizes, obtainment of a product with uniform quality and mainly, a faster beer production [7]. Continuous fermentation system with immobilized cells reduces even more the time of primary fermentation, which could be performed in only 1 day [8-11]. However, as the cost of the immobilization carrier is the major economic limitation for implementation of this system on industrial scale [12], the use of low-cost materials for cell immobilization is required. Brewer's spent grain, the main brewery by-product, is a low-cost material that has demonstrated high capacity of yeast cells retention. Besides its good performance as support for cell 
immobilization, this material presented a good stability and could be easily prepared, sterilized and regenerated. Due to these characteristics, brewer's spent grain has been considered a promising alternative as cell immobilization carrier [11, 13-15].

It is known that beer fermentation performance is affected by operational conditions such as temperature, concentration of wort, inoculum and dissolved oxygen, among others. A suitable control of these variables is thus of great interest for a good process performance and obtainment of high-quality products [16]. Among these variables, temperature is one of the most important, affecting not only the fermentation rate but also the beer flavor [17]. Several volatile compounds contribute to the beer flavor and the importance of them is not only determined by their individual concentration, but also by the simultaneous presence of other constituents (volatile and non-volatile) and their flavor threshold [18]. Around 600 volatile compounds have already been identified in beers; the most important include higher alcohols, esters and vicinal diketones [19]. Therefore, the present work evaluated the influence of temperature on fermentative parameters and formation of volatile compounds (higher alcohols, esters and vicinal diketones) during continuous high gravity brewing with yeasts immobilized on brewer's spent grains.

\section{Materials and methods}

Microorganism and inoculum preparation

The yeast employed in this study was a commercial lager brewing strain of Saccharomyces cerevisiae supplied by the IIIA (Instituto de Investigaciones para la Industria Alimenticia, Habana/Cuba). The stock culture was maintained on malt-extract agar slants at $4{ }^{\circ} \mathrm{C}$. For inoculum preparation, the cells were transferred to $500 \mathrm{ml}$ Erlenmeyer flasks containing $250 \mathrm{ml}$ all-malt diluted (10 ${ }^{\circ}$ Plato) wort and maintained under aerobic conditions on a rotary shaker (Cientec CT 713, Piracicaba/SP, Brazil) at $200 \mathrm{rpm}$, $30{ }^{\circ} \mathrm{C}$ for $30 \mathrm{~h}$. Then, the cells were separated by centrifugation at 3,500 rpm for $20 \mathrm{~min}$, washed with sterilized distilled water and added to the fermentation medium.

Wort production

High-gravity $\left(15^{\circ}\right.$ Plato) all-malt wort was produced in the EEL/USP pilot plant following standard brewing procedures. After hot trub removal in a whirlpool, the wort was autoclaved at $112{ }^{\circ} \mathrm{C}$ for $15 \mathrm{~min}$ and subsequently kept at $5{ }^{\circ} \mathrm{C}$ during 1 week for the cold trub formation. In order to remove the precipitated material, the wort was filtered using a plate and frame filter with filter sheets made of cellulose (Leitz KS80). This procedure allowed yeast cell mass assessment without trub interference. All-malt wort with original gravity of $10^{\circ}$ Plato was prepared by diluting the high-gravity wort with sterile brewery water. During continuous fermentation, the wort was maintained at $4{ }^{\circ} \mathrm{C}$ under a sterile $\mathrm{N}_{2}$ counter pressure (at ca. $0.2-0.4 \mathrm{psig}$ ).

\section{Carrier preparation}

To be used as cells' immobilization carrier, dried spent grains (10\% moisture content) were initially mixed with a $3 \%(\mathrm{v} / \mathrm{v}) \mathrm{HCl}$ solution in a solid:liquid ratio of $1: 15 \mathrm{~g}: \mathrm{ml}$, at $32 \mathrm{rpm}, 60{ }^{\circ} \mathrm{C}$ for $2.5 \mathrm{~h}$. The remaining solids were separated by filtration using $100 \%$ polyester cloth, washed with water until neutral $\mathrm{pH}$ and dried at $50{ }^{\circ} \mathrm{C}$ up to $10 \%$ moisture content. Subsequently, that material was treated with a $2 \%(\mathrm{w} / \mathrm{v}) \mathrm{NaOH}$ solution in a solid:liquid ratio of 3:50 g:ml, at $120 \mathrm{rpm}, 30^{\circ} \mathrm{C}$ for $24 \mathrm{~h}$. Finally, the solid residue was separated from the liquor by filtration, washed with water until neutral $\mathrm{pH}$ and dried at $50{ }^{\circ} \mathrm{C}$ up to $10 \%$ moisture content. The treated material was ground and sieved and only the particles that passed through a 16 mesh sieve (1.0 mm opening) and were retained in a 28 mesh sieve $(0.6 \mathrm{~mm}$ opening) were selected to be used as immobilization carrier during continuous fermentation.

\section{Bubble column reactor $(\mathrm{BCR})$}

A stainless steel BCR with an enlarged top section for degassing and a working volume of 5.21 (total volume of 9.7 1) was used. More details about the characteristics of this reactor were previously published [11]. Gas was injected at the bottom of the reactor through a stainless steel mesh $(0.26 \mathrm{~mm}$ opening). The sterile gas $(0.2 \mu \mathrm{m}$, Midisart 2000-Sartorius) flow rate was adjusted using a calibrated mass flow meter (Aalborg GFM 17). The temperature inside the reactor was maintained by means of a cooling jacket connected to a refrigeration bath. The continuous wort feed was carried out by means of a peristaltic pump (Masterflex C/L, Cole-Parmer). Prior to be used in the fermentation runs, the $\mathrm{BCR}$ reactor was sterilized by saturated steam at $121{ }^{\circ} \mathrm{C}$ for $30 \mathrm{~min}$. Afterward, it was loaded with $100 \mathrm{~g}$ of spent grains, sterilized again at $121{ }^{\circ} \mathrm{C}$ for $30 \mathrm{~min}$ and washed with 501 of sterile water.

\section{Starting and operating of BCR}

The reactor containing sterilized carrier was charged with high-gravity wort and inoculated with $500 \mathrm{ml}$ of inoculum. The initial $18 \mathrm{~h}$ of fermentation was performed batchwise aiming to reach a sufficiently high immobilized cell concentration $(>0.3 \mathrm{~g}$ cell $/ \mathrm{g}$ carr) inside the reactor. During 
this stage, carried out at $30{ }^{\circ} \mathrm{C}$ with a constant air flow rate of $250 \mathrm{ml} / \mathrm{min}$, the reactor was continually fed with diluted all-malt wort $\left(10^{\circ}\right.$ Plato). After this immobilization period, the diluted wort was replaced by the $15^{\circ}$ Plato wort. Fermentation was performed at three temperatures: 7, 10 and $15^{\circ} \mathrm{C}$, keeping constant the dilution rate $\left(D=0.05 \mathrm{~h}^{-1}\right)$ and total gas flow rate $\left(240 \mathrm{ml} / \mathrm{min}\right.$ of $\mathrm{CO}_{2}$ and $10 \mathrm{ml} / \mathrm{min}$ of air).

\section{Analytical methods}

Characterization of wort and green beer (apparent and real extract, apparent and real degrees of fermentation and ethanol) was performed by an automatic beer analyzer (Beer Analyser DSA 5000, Anton Paar, Austria). Total diacetyl was determined by gas chromatographic analysis of the static headspace. Higher alcohols ( $n$-propanol, isobutanol and amyl + isoamyl alcohol) and esters (ethyl acetate, isoamyl acetate and ethyl hexanoate) were analyzed by a headspace gas chromatograph with a flame ionized detector (FID) according to the current European Brewery Convention recommended methods [20]. The concentration of free amino nitrogen (FAN) was determined by standard procedures [21], using the ninhydrin method with samples absorption reading at $570 \mathrm{~nm}$.

Free yeast analyses

Viability was determined from the propagated yeast and from the free yeast in green beer by methylene blue staining [21]. Free yeast was counted in a Neubauer counting chamber. Cells that stained blue were counted as dead and unstained cells were considered to be viable.

\section{Immobilized biomass determination}

A sample of the fermentation medium containing about $1 \mathrm{~g}$ of immobilized biocatalyst (yeast + carrier) was placed in a 250-ml glass cylinder. The supernatant liquid (green beer) was removed and the carrier was washed with $200 \mathrm{ml}$ of distilled water. Afterward, the carrier was filtered on a stainless steel mesh $(0.26 \mathrm{~mm}$ opening), washed with $400 \mathrm{ml}$ of distilled water and dried at $105{ }^{\circ} \mathrm{C}$ for $12 \mathrm{~h}$. Aiming to remove the attached biomass from the carrier, approximately $0.5 \mathrm{~g}$ of dry biocatalyst was mixed with $100 \mathrm{ml}$ of $3 \%(\mathrm{w} / \mathrm{v}) \mathrm{NaOH}$ solution and maintained at $120 \mathrm{rpm}, 30{ }^{\circ} \mathrm{C}$ for $24 \mathrm{~h}$. The carrier free of cells was filtered on a stainless steel mesh $(0.15 \mathrm{~mm}$ opening), washed with $400 \mathrm{ml}$ of distilled water and then dried at $105{ }^{\circ} \mathrm{C}$ for $5 \mathrm{~h}$. The total immobilized cell biomass was determined by the weight difference before and after the carrier treatment with $\mathrm{NaOH}$. The carrier mass loss due to the alkaline treatment was quantified by blank experiments with clean carrier samples (without immobilized yeasts) and was discounted from the total immobilized cells biomass value.

\section{Fermentative parameters}

To evaluate the continuous fermentation performance, the following fermentative parameters were considered: rate of extract consumption $(\mathrm{g} / \mathrm{l} \mathrm{h}): \mathrm{Rs}=(\mathrm{Eo}-\mathrm{Ea}) \times D$; rate of ethanol production $(\mathrm{g} / \mathrm{l} \mathrm{h}): \mathrm{Rp}=P \times D$; maximum specific rate of extract consumption $\left(\mathrm{g}_{\text {ext }} / \mathrm{g}_{\text {cel }} \mathrm{h}\right)$ : $\mu_{S_{\text {máx }}}=(\mathrm{d} E / X \times \mathrm{d} t)_{\text {máx }} ;$ maximum specific rate of ethanol production $\left(\mathrm{g}_{\text {eth }} / \mathrm{g}_{\text {cel }} \mathrm{h}\right): \mu_{P_{\text {máx }}}=(\mathrm{d} P / X \times \mathrm{d} t)_{\text {máx }} ;$ maximum specific rate of cell growth $\left(\mathrm{h}^{-1}\right): \mu_{X_{\text {máx }}}=$ $(\mathrm{d} X / X \times \mathrm{dt})_{\text {máx }}$; where: dilution rate $\left(\mathrm{h}^{-1}\right): D=F / V$; residence time $(\mathrm{h}): t_{\mathrm{R}}=1 / D ; F=$ feed rate of wort $(1 / \mathrm{h})$; $V=$ volume of wort in the reactor (1); Eo $=$ wort original gravity $(\mathrm{g} / \mathrm{l}) ; \mathrm{Ea}=$ beer apparent extract at the reactor overflow $(\mathrm{g} / \mathrm{l}) ; P=$ ethanol concentration at the reactor overflow $(\mathrm{g} / \mathrm{l}) ; X=$ free cell concentration at the reactor overflow $(\mathrm{g} / \mathrm{l}) ; \mathrm{d} X(\mathrm{~g} / \mathrm{l})=$ free cell concentration at the reactor overflow in the instant $\mathrm{d} t(\mathrm{~g} / \mathrm{l}) ; \mathrm{d} E=$ concentration of extract consumed in the instant $\mathrm{dt}(\mathrm{g} / \mathrm{l}) ; \mathrm{d} P=$ concentration of ethanol produced in the instant $\mathrm{d} t(\mathrm{~g} / \mathrm{l})$. The maximum specific rates $\left(\mu_{X_{\text {máx }}}, \mu_{S_{\text {máx }}}, \mu_{P_{\text {máx }}}\right)$ were calculated through the method proposed by Le Duy and Zajic [22].

\section{Results and discussion}

Fermentative parameters of continuous fermentation

Primary high-gravity beer fermentation by continuous process was evaluated through an experiment performed at three different temperatures: 15,10 and $7{ }^{\circ} \mathrm{C}$. During fermentation, the system was considered to be in stationary state for each temperature, after a minimum period of ten residence times $(200 \mathrm{~h})$.

It can be observed in Fig. 1 that the apparent extract consumption decreased when the fermentation temperature was reduced. Therefore, the extract concentration in the medium was increased, and consequently, the ethanol concentration in the beer at the reactor outflow was reduced. In the final stage of the process, when the temperature was increased from 7 to $15^{\circ} \mathrm{C}$, the apparent extract consumption increased, and thus, a higher ethanol concentration $(6 \% \mathrm{v} / \mathrm{v})$ was obtained in the produced beer. According to Brányik et al. [23], the increase in fermentation temperature favors cell growth or improves the metabolic activity of the microorganism, providing a higher consumption of wort sugars and increasing the ethanol concentration as a consequence.

Total cell $\left(X_{\text {total }}\right)$ and free cell $\left(X_{\text {free }}\right)$ concentrations inside the reactor were also influenced by the fermentation 


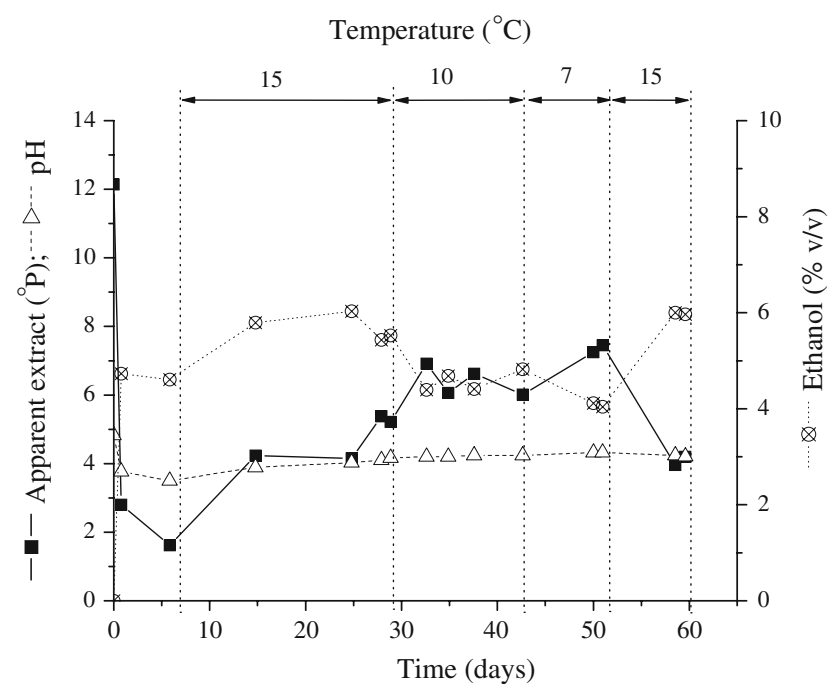

Fig. 1 Influence of temperature on concentration of apparent extract, ethanol and $\mathrm{pH}$ during continuous fermentation of $15^{\circ}$ Plato wort (allmalt) in a bubble column reactor (gas flow rate: $240 \mathrm{ml} / \mathrm{min}^{\mathrm{CO}} \mathrm{O}_{2}$ and $10 \mathrm{ml} / \mathrm{min}$ air; dilution rate: $0.05 \mathrm{~h}^{-1}$ )

temperature (Fig. 2). For both cases, cell concentration decreased with the temperature reduction. Nevertheless, the total cell concentration (free + immobilized per volume of reactor) was maintained in elevated values (higher than $19 \mathrm{~g} / \mathrm{l})$ throughout the continuous fermentation.

The free cell concentration $\left(X_{\text {free }}\right)$ dependence with temperature cannot only be considered as a result of the variations in the kinetic of free cells growth, because the immobilized cells growth rate also influence $X_{\text {free }}$ through the loss of cells from yeast layer on the carrier surface [23].

On the contrary of free cell and total cell concentration, the concentration of cells immobilized on spent grains ( $g$

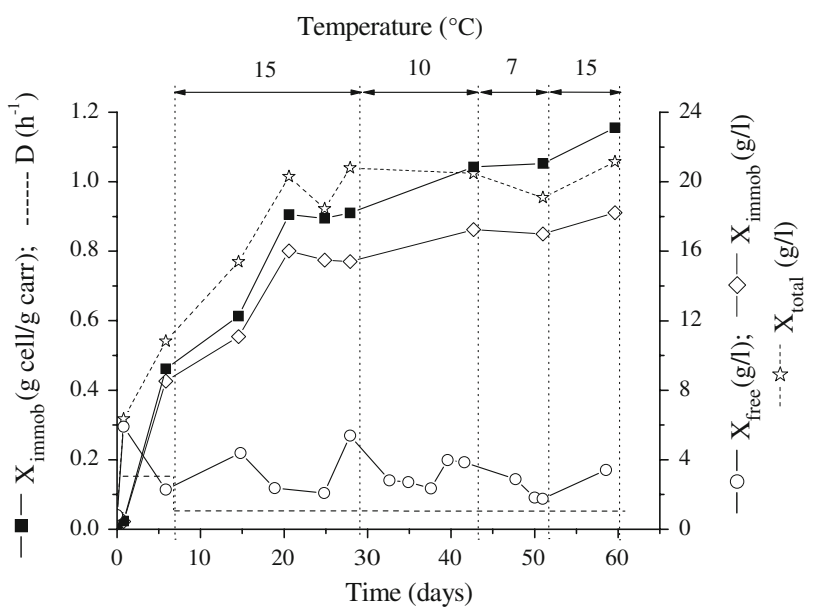

Fig. 2 Influence of temperature on concentration of free $\left(X_{\text {free }}\right)$, immobilized $\left(X_{\text {immob }}\right)$ and total $\left(X_{\text {total }}\right)$ cells during continuous fermentation of $15^{\circ}$ Plato wort (all-malt) in a bubble column reactor (gas flow rate: $240 \mathrm{ml} / \mathrm{min} \mathrm{CO}_{2}$ and $10 \mathrm{ml} / \mathrm{min}$ air; dilution rate: $0.05 \mathrm{~h}^{-1}$ ) cell/g carrier) was not affected by the temperature, since it continuously increased up to $1.16 \mathrm{~g}$ cell $/ \mathrm{g}$ carr at the end of fermentation. Brányik et al. [23] also reported a non significant effect of the temperature (from 13 to $16{ }^{\circ} \mathrm{C}$ ) in the concentration of yeasts immobilized on spent grains, during the continuous fermentation of $14^{\circ}$ Plato wort in a gaslift reactor using a constant gas flow rate of $250 \mathrm{ml} / \mathrm{min}$. However, in that work, the authors found similar values of immob (about $0.65 \mathrm{~g}$ cell $/ \mathrm{g}$ carr), independently of the used temperature. On the other hand, these authors observed a gradual disintegration of the spent grains particles, caused by the collisions of them each other and with the reactor wall. Due to disintegration, the particles became smaller and were lost through the duct at the reactor outflow. The mechanic stress originated by these collisions could have been one of the reasons for the lower $X_{\text {immob }}$ value ( $\approx 0.65 \mathrm{~g}$ cell $/ \mathrm{g}$ carr) found by these authors, compared with the maximum value (1.16 g cell/g carr) obtained in the present study. According to Verbelen et al. [24], the gas-lift reactor provides a more intense circulation than the $\mathrm{BCR}$, for a same gas flow rate, due to the internal circulation duct that generates a region of "ascension" in the reactor centre, and a "descent" region outside the duct. In addition, physiological differences among yeasts and variations in the composition of worts are also factors that can be related to the differences in the values of $X_{\mathrm{immob}}$ obtained in both studies.

Figure 3 shows that the viability of free cells in suspension was not influenced by the fermentation temperature, remaining in approximately $90 \%$ throughout the experiment. It can also be noted in this figure that the ratio between free cell concentration determined by counting in a Neubauer chamber (cell/ml) and by dry weight $(\mathrm{g} / \mathrm{l})$ was almost constant, with $1 \times 10^{7} \mathrm{cell} / \mathrm{ml}$ for

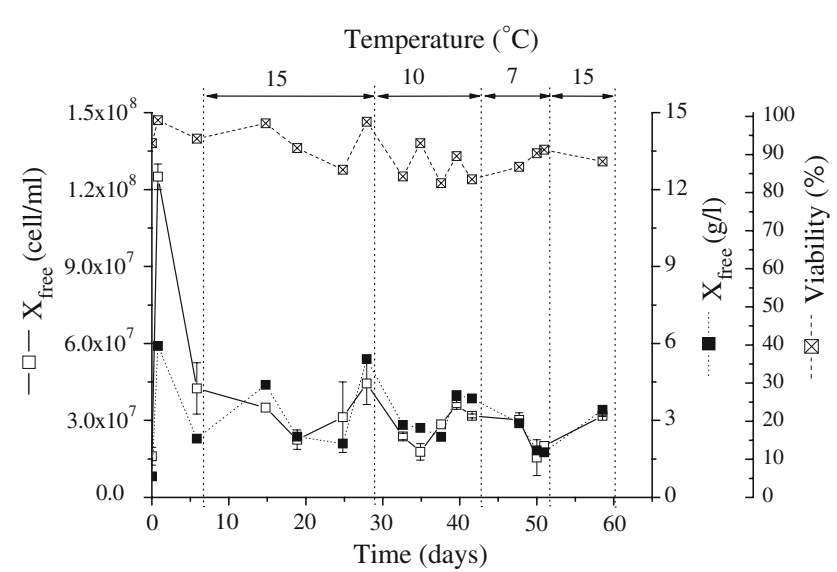

Fig. 3 Influence of temperature on viability and concentration of free cells $\left(X_{\text {free }}\right)$, determined by Neubauer counting chamber $($ cell $/ \mathrm{ml})$ and by dry weight $(\mathrm{g} / \mathrm{l})$, during continuous fermentation of $15^{\circ}$ Plato wort (all-malt) in a bubble column reactor (gas flow rate: $240 \mathrm{ml} / \mathrm{min} \mathrm{CO}_{2}$ and $10 \mathrm{ml} / \mathrm{min}$ air; dilution rate: $0.05 \mathrm{~h}^{-1}$ ) 
each $1.0 \mathrm{~g} / \mathrm{l}$. Thus, free cells in suspension presented an average specific weight of $10^{-10} \mathrm{~g} /$ cell during the continuous fermentation.

The fermentative parameters obtained for each temperature are depicted in Table 1. Note that the consumption of FAN, apparent and real degrees of fermentation, rate of extract consumption and ethanol volumetric productivity increased when the fermentation temperature was raised. The increase of temperature also favored the ethanol volumetric productivity during the discontinuous fermentation of 15 and $20^{\circ}$ Plato worts [1], and the sugars consumption rate during discontinuous fermentation of worts with approximately $10^{\circ}$ Plato [25]. According to Engasser et al. [25], the influence of temperature on the consumption of wort sugars such as glucose or maltose, can be represented by a dependence of the Arrhenius type, between the maximum sugars consumption rate and the fermentation temperature.

The specific rates of extract consumption $\left(\mu_{S}\right)$ and ethanol production $\left(\mu_{P}\right)$ were also directly related to the temperature, since $\mu_{S}$ and $\mu_{P}$ increased as the fermentation temperature was raised. Similar effect of the temperature on maximum specific rates of extract consumption and ethanol production was reported during the discontinuous fermentation of $15^{\circ}$ Plato wort in a pilot plant (140 l) $[1,26]$.

Comparison with fermentative parameters

of discontinuous fermentations

In this stage, fermentations were also performed with $15^{\circ}$ Plato wort, at 15,10 and $7{ }^{\circ} \mathrm{C}$, but in anaerobiose and by discontinuous process without immobilized yeasts (only free cells), aiming to compare the fermentative parameters of the discontinuous process with those obtained during the continuous fermentation with yeasts immobilized on spent grains. For a better comparison of these parameters, discontinuous fermentations were evaluated at the times where the ethanol concentrations were the same to those achieved during continuous fermentation for the different temperatures. Thus, the discontinuous assays at 15, 10 and $7{ }^{\circ} \mathrm{C}$ were analyzed when the ethanol concentrations were 5.5, 4.8 and $4 \%(\mathrm{v} / \mathrm{v})$, respectively (Table 2$)$. The maximum specific rates of cell growth, extract consumption and ethanol production were calculated from adjusted data of concentration of cells in suspension, extract and ethanol during the exponential growth phase, using the method proposed by Le Duy and Zajic [22].

As shown in Table 2, higher temperatures lead to a reduction in the time necessary to attain the desired ethanol concentration. According to Munroe [27], fermentation rates increase with temperature by increasing the rate of yeast metabolism, giving higher specific fermentation rates. Thus, discontinuous fermentation of high-gravity worts can be completed faster when the temperature is raised [28].

Comparing the fermentative parameters obtained in the discontinuous (Table 2) and continuous (Table 1) processes, it can be observed that the apparent and real extract, and apparent and real degree of fermentation were close similar for the same temperatures. Otherwise, the rate of extract consumption and ethanol volumetric productivity during continuous fermentation were higher than those obtained in the discontinuous processes, the difference being greater for the lower temperatures. In numeric terms, the rates of extract consumption during the continuous process were 218, 367 and 525\% higher when compared to discontinuous fermentation at 15,10 and $7{ }^{\circ} \mathrm{C}$, respectively. Likewise, the ethanol volumetric productivities during continuous fermentation were 219, 369 and $536 \%$ higher than those obtained for the discontinuous process at 15,10 and $7{ }^{\circ} \mathrm{C}$, respectively. The significant increase in these two parameters during continuous fermentation is the result of the elevated concentration of
Table 1 Fermentative parameters obtained during continuous fermentation of $15^{\circ}$ Plato wort $(100 \%$ malt $)$ in a bubble column reactor (gas flow rate: $240 \mathrm{ml} / \mathrm{min} \mathrm{CO}_{2}$ and $10 \mathrm{ml} / \mathrm{min}$ air; dilution rate: $0.05 \mathrm{~h}^{-1}$ ), at different temperatures after attaining the stationary state

a Initial stage

b End stage

\begin{tabular}{|c|c|c|c|c|}
\hline & \multicolumn{4}{|c|}{ Temperature $\left({ }^{\circ} \mathrm{C}\right)$} \\
\hline & $15^{\mathrm{a}}$ & 10 & 7 & $15^{\mathrm{b}}$ \\
\hline Ethanol (\% v/v) & 5.5 & 4.8 & 4.0 & 6.0 \\
\hline Apparent extract ( ${ }^{\circ}$ Plato) & 5.2 & 6.0 & 7.5 & 4.2 \\
\hline Real extract ( ${ }^{\circ}$ Plato) & 7.2 & 7.7 & 8.8 & 6.3 \\
\hline Free amino nitrogen (FAN) (mg/l) & 115 & 125 & 128 & 109 \\
\hline FAN consumption (mg/l) & 65 & 55 & 52 & 69 \\
\hline Apparent degree of fermentation (\%) & 65.9 & 59.4 & 49.5 & 72.2 \\
\hline Real degree of fermentation (\%) & 55.3 & 50.0 & 42.0 & 60.4 \\
\hline Rate of extract consumption (g/l.h) & 5.37 & 4.58 & 3.50 & 5.61 \\
\hline Ethanol volumetric productivity (g/l.h) & 2.14 & 1.83 & 1.40 & 2.24 \\
\hline Specific rate of extract consumption $\left(\mathrm{g}_{\text {ext }} / \mathrm{g}_{\text {cel }} \mathrm{h}\right)$ & 0.258 & 0.223 & 0.183 & 0.266 \\
\hline Specific rate of ethanol production $\left(\mathrm{g}_{\text {eth }} / \mathrm{g}_{\text {cel }} \mathrm{h}\right)$ & 0.103 & 0.089 & 0.073 & 0.106 \\
\hline
\end{tabular}


Table 2 Fermentative parameters obtained during discontinuous fermentation of $15^{\circ}$ Plato wort $(100 \%$ malt) in a bubble column reactor, at different temperatures after attaining the stationary state

\begin{tabular}{|c|c|c|c|}
\hline & \multicolumn{3}{|c|}{ Temperature $\left({ }^{\circ} \mathrm{C}\right)$} \\
\hline & 15 & 10 & 7 \\
\hline Ethanol $(\% \mathrm{v} / \mathrm{v})$ & 5.5 & 4.8 & 4.0 \\
\hline Fermentation time $(\mathrm{h})$ & 64 & 97 & 142 \\
\hline Apparent extract $\left({ }^{\circ} \mathrm{Plato}\right)$ & 4.9 & 6.3 & 7.6 \\
\hline Real extract ( ${ }^{\circ}$ Plato) & 6.8 & 7.9 & 9.0 \\
\hline Apparent degree of fermentation (\%) & 67.3 & 58.6 & 49 \\
\hline Real degree of fermentation (\%) & 56.4 & 49.3 & 41.5 \\
\hline$\mu_{X_{\max }} /$ Fermentation time $(\mathrm{h})$ & $0.066 / 5$ & $0.043 / 10$ & $0.029 / 5$ \\
\hline Rate of extract consumption $(\mathrm{g} / \mathrm{l} \mathrm{h})$ & 1.69 & 0.98 & 0.56 \\
\hline$\mu_{S_{\text {max }}} /$ Fermentation time $(\mathrm{h})$ & $0.939 / 20$ & $0.640 / 10$ & $0.559 / 35$ \\
\hline $\begin{array}{l}\text { Ethanol volumetric productivity } \\
\quad(\mathrm{g} / \mathrm{l} \mathrm{h})\end{array}$ & 0.67 & 0.39 & 0.22 \\
\hline$\underline{\mu_{P_{\text {máx }}} / \text { Fermentation time }(\mathrm{h})}$ & $0.368 / 30$ & $0.277 / 40$ & $0.263 / 40$ \\
\hline
\end{tabular}

total cells (free + immobilized) maintained in the BCR throughout the process. On the other hand, the maximum specific rates of extract consumption during the discontinuous process were 264, 187 and 205\% higher than those obtained during the continuous fermentation at 15, 10 and $7{ }^{\circ} \mathrm{C}$, respectively, while the maximum specific rates of ethanol production for discontinuous fermentation were 257, 211 and $260 \%$ higher when compared to the continuous process at 15,10 and $7{ }^{\circ} \mathrm{C}$, respectively. It is important to emphasize that the specific rates for the continuous fermentation were calculated considering the sum of free and immobilized cells concentrations. According to Brányik et al. [23], the specific rate of extract consumption during continuous fermentation with immobilized cells can be calculated by the ratio between extract consumption rate and the respective total cell concentration (free + immobilized).

The metabolism of the immobilized cells varies according to the cells' position on the carrier [29]. Cells located on the surface are in direct contact with the wort and act as free cells in suspension [10]. Thus, the results obtained in our study suggest that the cells' metabolism in the continuous system was slower than the free cells metabolism in the discontinuous system, due to the way of process conduction. According to Brányik et al. [30] the average biofilm thickness of yeasts immobilized on spent grains is ca. $10 \mu \mathrm{m}$. Therefore, the lower metabolic activity can be attributed to different physiological conditions (i.e., "aging") of the immobilized cells, instead of limitations of substrate diffusion through the yeast layer.
Another interesting comparison is regarding the volume of beer produced in both process, the continuous and discontinuous fermentation. At the end of the discontinuous fermentations $\left(64,97\right.$ and $142 \mathrm{~h}$ at 15,10 and $7{ }^{\circ} \mathrm{C}$, respectively), the volume of beer produced was equal to the working volume of the BCR (5.2 1). Considering these times of fermentation, the calculated volume of beer obtained during the continuous fermentation $\left(D=0.05 \mathrm{~h}^{-1}\right)$ in the BCR would be 16.64, 25.22 and 36.921 , at 15,10 and $7{ }^{\circ} \mathrm{C}$, respectively. Thus, the continuous process would permit increases of 220,385 , and $610 \%$ in the volume of beer produced when compared with the discontinuous processes performed at 15,10 and $7^{\circ} \mathrm{C}$, respectively.

\section{Production of compounds related to beer flavor}

The concentration of volatile compounds related to beer flavor (esters, higher alcohols, and diacetyl) was also determined during continuous fermentation for each temperature (Table 3). Ethyl acetate was the major ester found in the beers produced by continuous fermentation. In fact, ethyl acetate is the ester present in highest concentration in beers, corresponding normally to more than $30 \%$ of the total ester concentration [31].

Regarding the production of total ester, it was verified an increasing production of these compounds when the fermentation temperature was decreased. The literature data about the effect of the temperature on ester formation are contradictory. While some authors reported an increase

Table 3 Volatile compounds' production during continuous fermentation of $15^{\circ}$ Plato wort $(100 \%$ malt $)$ in a bubble column reactor (gas flow rate: $240 \mathrm{ml} / \mathrm{min} \mathrm{CO}_{2}$ and $10 \mathrm{ml} / \mathrm{min}$ air; dilution rate: $0.05 \mathrm{~h}^{-1}$ ), at different temperatures after attaining the stationary state

\begin{tabular}{lrrrr}
\hline Compound $(\mathrm{mg} / \mathrm{l})$ & \multicolumn{5}{c}{ Temperature $\left({ }^{\circ} \mathrm{C}\right)$} \\
\cline { 2 - 5 } & \multicolumn{1}{c}{$15^{\mathrm{a}}$} & \multicolumn{1}{c}{10} & \multicolumn{1}{c}{} & \multicolumn{1}{c}{$15^{\mathrm{b}}$} \\
\hline Total esters & 46.27 & 48.74 & 104.88 & 54.17 \\
Ethyl acetate & 44.40 & 48.20 & 103.90 & 52.90 \\
Isoamil acetate & 1.45 & 0.38 & 0.81 & 0.98 \\
Ethyl hexanoate & 0.42 & 0.16 & 0.17 & 0.29 \\
Total higher alcohols & 111.60 & 81.10 & 73.30 & 121.70 \\
$n$-propanol & 29.20 & 18.00 & 15.60 & 32.40 \\
Isobutanol & 16.20 & 12.00 & 11.70 & 18.60 \\
Amyl + isoamyl alcohol & 66.20 & 51.10 & 46.00 & 70.70 \\
Alcohols: esters ratio & $2.4: 1$ & $1.7: 1$ & $0.7: 1$ & $2.2: 1$ \\
Diacetyl & $\mathrm{NA}$ & 0.555 & 0.488 & 0.685 \\
\hline
\end{tabular}

$N A$ not analyzed

${ }^{a}$ Initial stage

$\mathrm{b}$ End stage 
in ester production by decreasing the fermentation temperature [32], others [31, 33] related that decreases in the fermentation temperature lead to lower ester formation. In fact, the influence of temperature on ester production is not the same for all the yeasts strains [9], due to variations in the activity of the alcohol acetyltransferase enzyme among the different microorganism species [34].

In contrast to the total ester concentration, the total higher alcohols concentration decreased when the fermentation temperature was reduced (Table 3). It has been stated that yeast growth limiting conditions, such as low temperatures or high pressures, reduce the higher alcohols production [33]. Among these conditions, the formation of higher alcohols is more susceptible to temperature variations [19]. On the other hand, conditions that promote yeasts growth, such as increase of oxygen availability and wort supplementation with amino acids, stimulate the production of these alcohols [33]. Reduction in the concentration of total higher alcohols due to the fermentation temperature decrease (from 15 to $0{ }^{\circ} \mathrm{C}$ ) was also observed by Kopsahelis et al. [35] during repeated discontinuous fermentation with yeasts immobilized in partially delignified spent grains. The results obtained by these authors ( 81 up to $119 \mathrm{mg} / \mathrm{l}$ ) were lower than the concentration found in maturated beers $(130 \mathrm{mg} / \mathrm{l})$.

As well as for total higher alcohols, the diacetyl concentration in the beer at the reactor outflow also increased as the fermentation temperature was raised (Table 3). Similar behavior was observed by Smogrovicová and Dömény [31] at $5-20{ }^{\circ} \mathrm{C}$, during the discontinuous wort fermentation with yeasts immobilized in DEAE-cellulose. Some authors [33] consider that the diacetyl concentration in fermented worts depends on the rate of formation of the diacetyl precursor ( $\alpha$-acetolactate), as well as on the rates of the oxidative decarboxylation of this precursor to form diacetyl and also to the diacetyl reduction into acetoin. Thus, fermentation conditions that favor yeast growth, such as elevated temperatures, can increase the levels of $\alpha$ acetolactate, and consequently, the diacetyl concentration in the fermented wort [19].

It is important to detach that diacetyl exerts great influence on beer flavor, since its presence in elevated concentrations $(>0.20 \mathrm{mg} / \mathrm{l})$ confers a butter-like flavor to the matured beer [18]. In the present work, high diacetyl concentrations were obtained in all produced beers, independently of the fermentation temperature. However, such values are in the levels normally found in non-maturated beer ("green beer"). After maturation, the diacetyl concentration in the beer is reduced. Green beer with diacetyl concentrations $(0.4$ up to $0.6 \mathrm{mg} / \mathrm{l})$ similar to those found in the present work was also produced by continuous fermentation in a recent study [23]. After 10 days of discontinuous maturation at $4{ }^{\circ} \mathrm{C}$, the diacetyl concentration in that beer was reduced to less than $0.05 \mathrm{mg} / \mathrm{l}$, being thus below of its flavor threshold. On the other hand, beer flavor is not only dependent on the absolute individual quantity of each compound, but also on the relative quantity between higher alcohols and esters. According to the literature data, the optimum ratio between higher alcohols and esters (A:E) vary between 2.5-3:1 [31] and 4.1-4.7:1 [30]. In the present work, an A:E ratio similar to those optimum values were obtained during the continuous high-gravity beer fermentation at $15{ }^{\circ} \mathrm{C}(2.2-2.4: 1)$.

In conclusion, the fermentative parameters and flavor volatile compounds' formation during continuous highgravity beer fermentation in a BCR were significantly influenced by the temperature. The apparent and real degrees of fermentation, rate of extract consumption, ethanol volumetric productivity and consumption of FAN increased as the fermentation temperature was raised from 7 to $15^{\circ} \mathrm{C}$, keeping constant the dilution rate $\left(0.05 \mathrm{~h}^{-1}\right)$ and the total gas flow rate $\left(240 \mathrm{ml} / \mathrm{min}\right.$ of $\mathrm{CO}_{2}$ and $10 \mathrm{ml} / \mathrm{min}$ of air) throughout the process. In addition, the beer produced at $15^{\circ} \mathrm{C}$ presented a higher alcohols to esters ratio (2.2-2.4:1) similar to the optimum values described in literature. It was thus concluded that primary fermentation of high gravity $\left(15^{\circ} \mathrm{Plato}\right)$ all-malt wort by continuous process with yeasts immobilized on spent grains, can be carried out with good performance at $15{ }^{\circ} \mathrm{C}$.

Perhaps the results achieved at the lower temperatures (7 and $10^{\circ} \mathrm{C}$ ) could be improved by selecting other conditions of dilution rate and total gas flow rate for the continuous fermentation. For example, fermentation of $15^{\circ}$ Plato all-malt wort at $7{ }^{\circ} \mathrm{C}$ could be performed at a lower dilution rate (higher residence time) to increase the ethanol concentration and modify the beer flavor profile.

Acknowledgments We would like to express our gratefulness to the agencies: FAPESP (Fundação de Amparo à Pesquisa do Estado de São Paulo), CAPES (Coordenação de Aperfeiçoamento de Pessoal de Nível Superior) and CNPq (Conselho Nacional de Desenvolvimento Científico e Tecnológico), for the financial assistance provided. We also gratefully acknowledge the companies: Malteria do Vale, Corn Products Brasil, Wallerstein Industrial e Comercial, JohnsonDiversey, and Femsa Brasil.

\section{References}

1. Dragone G, Silva DP, Almeida e Silva JB, Lima UA (2003) Biotechnol Lett 25:1171-1174

2. Dragone G, Silva DP, Almeida e Silva JB (2004) Lebensm Wiss Technol 37:797-802

3. Cunningham S, Stewart GG (1998) J Am Soc Brew Chem 56:12-18

4. Stewart GG, Bothwick R, Bryce J, Cooper D, Cunningham S, Hart C, Rees E (1997) MBAA Tech Quart 34:264-270

5. Hackstaff BW (1978) MBAA Tech Quart 15:1-7

6. McCaig R, McKee J, Pfisterer EA, Hysert DA, Munoz E, Ingledew WM (1992) J Am Soc Brew Chem 50:18-26 
7. Virkajärvi I, Vainikka M, Virtanen H, Home S (2002) J Am Soc Brew Chem 60:188-197

8. Mensour N, Margaritis A, Briens CL, Pilkington H, Russell I (1996) Immobilized yeast applications in the brewing industry. In: Wijffels RH, Buitelaar RM, Bucke C, Tramper J (eds) Immobilized cells: basics and applications. Elsevier Science, Amsterdam, pp 3-16

9. Verstrepen KJ, Derdelinckx G, Dufour J-P, Winderickx J, Thevelein JM, Pretorius IS, Delvaux FR (2003) J Biosci Bioeng 96:110-118

10. Brányik T, Vicente AA, Dostálek P, Teixeira JA (2005) Biotechnol Progr 21:653-663

11. Dragone G, Mussatto SI, Almeida e Silva JB (2007) J Inst Brew 113:391-398

12. Linko M, Haikara A, Ritala A, Penttilä M (1998) J Biotechnol 65:85-98

13. Brányik T, Vicente AA, Cruz JMM, Teixeira JA (2001) Biotechnol Lett 23:1073-1078

14. Dragone G, Mussatto SI, Almeida e Silva JB (2007) Ci Tecnol Aliment 27 (Suppl):37-40

15. Mussatto SI, Dragone G, Roberto IC (2006) J Cereal Sci 43:1-14

16. Briggs DE, Boulton CA, Brookes PA, Stevens R (2004) Brewing: science and practice. Woodhead, Cambridge

17. Debourg IA (1993) Cerevisia Biotechnol 18:25-30

18. Angelino SAGF (1991) Beer. In: Maarse H (ed) Volatile compounds in foods and beverages. Marcel Dekker, New York, pp $581-616$

19. Willaert R, Nedovic VA (2006) J Chem Technol Biotechnol 81:1353-1367

20. European EBC-, Convention Brewery (2004) Analytica-EBC. Fachverlag Hans Carl, Nürnberg

21. ASBC - American Society of Brewing Chemists (1996) Methods of Analysis of the American Society of Brewing Chemists, 8th edn. The Technical Committee and the Editorial Committe of the ASBC, Minnesota

22. Le Duy A, Zajic JE (1973) Biotechnol Bioeng 15:805-815

23. Brányik T, Vicente AA, Cruz JMM, Teixeira JA (2004) J Am Soc Brew Chem 62:29-34

24. Verbelen PJ, de Schutter DP, Delvaux F, Verstrepen KJ, Delvaux FR (2006) Biotechnol Lett 28:1515-1525

25. Engasser JM, Marc I, Moll M, Duteurtre B (1981) Kinetic modelling of beer fermentation. In Proceedings of the 18th European Brewery Convention. IRL Press, London, pp 579-586

26. Dragone G (2002) Estudo cinético do processo fermentativo de produção de cervejas em mostos concentrados. MSc. Dissertation, Faculty of Chemical Engineering of Lorena, Brazil

27. Munroe JH (1994) Fermentation. In: Hardwick WA (ed) Handbook of brewing. Marcel Dekker, New York, pp 323-353

28. Casey GP, Magnus CA, Ingledew WM (1984) Appl Environ Microb 48:639-646

29. Willaert R (2000) Minerva Biotechnol 12:319-330

30. Brányik T, Vicente AA, Teixeira, JA (2005) Braz J Food Technol Mar 3:74-79

31. Smogrovicová D, Dömény Z (1999) Process Biochem 34: 785-794

32. Kunze W (1996) Technology Brewing and Malting International ed. VLB, Berlin

33. Stewart GG, Russell I (1998) An introduction to brewing science and technology series III brewer's yeast. The Institute of Brewing, London

34. Ramos-Jeunehomme C, Laub R, Masschelein CA (1991) Why is ester formation in brewery fermentations yeast strain dependent? In Proceedings of the 23rd European Brewery Convention. Oxford University Press, London, pp 257-264

35. Kopsahelis N, Kanellaki M, Bekatorou A (2007) Food Chem 104:480-488 